\title{
Zoledronic Acid Treatment of Bone Metastasis in Urology
}

\author{
Kemik Metastazlı Ürolojik Olgularda Zoledronik Asit Tedavisi \\ Muammer Aydın, Zafer Tandoğdu, Arif Özkan \\ Clinic of Urology, Taksim Training and Research Hospital, İstanbul, Turkey
}

\begin{abstract}
Bone is a frequent site of metastasis and particularly prostate, breast, renal and multiple myeloma are the more common tumors that metastasize. Almost $70 \%$ of men with advanced prostate cancer and one-third of patients with renal cancer develop metastasis to the bone. Significant skeletal complications in these patients are due to distortion of bony tissue by metastasis, osteoporosis and androgen deprivation therapy associated bone tissue loss. Impaired bone health affects the qualityof life due to events such as pathological fractures, spinal cord compression, malignant hypercalcemia and treatments required for them. Treatment options of patients with bone metastases are radiotherapy, chemotherapy, orthopedic surgery and biphosphonates. Zoledronic acid is a new generation bisphosphonate, which is accepted as the gold standard in the medical treatment of bone metastases of solid tumors. This drug has an appropriate safety and tolerability profile. Zoledronic acid reduces and delays skeletally related events and have a significant impact on the total risk compared to placebo. The aim of this review is to evaluate and summarize the use of zoledronic acid in urological malignancies with bone metastases. (JAREM 2013; 3: 5-7)
\end{abstract}

Key Words: Bone metastasis, zoledronic acid, urologic malignities

\section{ÖZET}

Kemiğe en çok metastaz yapan kanserler meme, prostat, multipl myelom ve böbrek kanseri olgularıdır. Illerlemiş prostat kanserli hastaların yaklaşık \%70'inde, renal kanserli olguların ise üçte birinde kemik metastazı gelişir. Metastatik odaklardaki bozuk kemik dokusu, altta yatan osteoporoz ve prostat kanserinde kullanılan androjen deprivasyon tedavisinin yarattığı kemik dokusu kaybı bu hastalarda önemli iskelet komplikasyonları riski oluşturur Bunlar; patolojik kırıklar, spinal kanal kompresyonu, malin hiperkalsemi, kemik ağrıları gibi durumlar olup gerek durumun kendisi gerekse yapılacak ilave tedavilerin etkisiyle hastaların yaşam kalitesini önemli ölçüde olumsuz etkiler. Günümüzde kemik metastazlı hastaların tedavisinde kullanılan yöntemler: Radyasyon, kemoterapi, ortopedik cerrahi ve bifosfonatlardır. Zoledronik asit, kemik metastazlı solid tümörlerin medikal tedavisinde altın standart olarak kabul edilen yeni jenerasyon bifosfonattır. Uygun bir güvenlik ve tolerabilite profiline sahip olan bu drog, kemik olaylarının insidansını azaltıp, başlangıcını geciktirerek total riskte plaseboya kıyasla önemli ölçüde etkili olmuştur. Bu yazıda üroloji için yeni sayılabilecek bu ilacın kemik metastazlı ürolojik olgularda kullanımı ile ilgili önemli olgulara dikkat çekilmeye çalışılmıştır. (JAREM 2013; 3: 5-7)

Anahtar Sözcükler: Kemik metastazi, zoledronik asid, urolojik maligniteler

\section{INTRODUCTION}

Both the underlying osteoporosis and the administered medical treatment in metastatic advanced cancers are associated with reduced bone tissue integrity. Smoking, alcohol, hypogonadism, low calcium diet and sedentary lifestyle are associated with increased risk of bone loss. These factors increase the probability of significant skeletal related events (SRE). Bone pain, pathologic fractures, spinal cord compression and malignant hypercalcemia are the major SREs encountered. Both the SREs and the treatments required impair the quality of life, mortality and morbidity significantly $(1,2)$.

The current treatment options of skeletal complications are radiotherapy, chemotherapy, orthopedic surgery and intravenous (IV) bisphosphonates. Bisphosphonates reduce the SRE incidence by 25 to $50 \%$ and constitute an important part of the conservative strategy (3).

Zoledronic acid is a new generation bisphosphonate and clinical trials revealed the benefit in treatment of bone metastases of solid tumors such as prostate, renal and lung cancers. The U.S. Food and Drug Administration (FDA) approved Zoledronic acid in February 2002. In a short time after this date in July 2002 the
European Agency for the Evaluation of Medicinal Products approved the drug in Europe.

\section{Zoledronic Acid in Urologic Tumors}

Metastases to bone are mostly from breast, prostate, renal cancers and multiple myeloma. Bone is a common site of metastatic spread in patients with advanced renal cell carcinoma (RCC), occurring in one third of patients. Bone metastasis in these patients reduces the two-year survival to $10-20 \%(4,5)$. The majority of RCC metastatic spread to the bone is osteolytic in nature. Additional complications which may arise such as; malignant hypercalcemia, bone fracture and bone pain can be managed with radiotherapy (6). In a placebo controlled randomized phase III study, a significant reduction in SREs was shown in the Zoledronic acid treatment group in RCC patients. The majority of patients had at least one skeletal complication before the study (zoledronic acid group 81\%, placebo group 95\%). This study showed that Zoledronic acid delayed complications by approximately 12 months compared with placebo and decreased the total complication risk by $58 \%$ (7). Unfortunately there are not many studies exploring the issue and the studies that are available were carried outbefore the targeted therapy era. Future studies evaluating the issue will be of benefit. Current literature has shown that 


\begin{tabular}{|c|c|}
\hline Timing of treatment & - At the time of diagnosis of bone metastasis of all solid tumors \\
\hline Duration of treatment & $\begin{array}{l}\text { - As long as the patient can tolerate the treatment and there is a significant decrease in the } \\
\text { performance status of the patient } \\
\text { - Unfortunately the optimal duration is still to be defined. }\end{array}$ \\
\hline Serum creatinine levels & $\begin{array}{l}\text { - } 10 \text { days prior to the initial infusion. } \\
\text { - Should be checked prior to each infusion }\end{array}$ \\
\hline Criteria to postpone treatment & $\begin{array}{l}\text { - Treatment should be postponed if creatinine levels are above } 3 \mathrm{mg} / \mathrm{dL} \\
\text { - If the increase in creatinine levels do not resolve within } 4 \text { to } 8 \text { weeks the treatment should be } \\
\text { stopped }\end{array}$ \\
\hline Acute phase reaction & $\begin{array}{l}\text { - Fever, arthralgia, myalgia, nausea, increased bone pain } \\
\text { - Self limited } \\
\text { - Occurs within } 24 \text { hours of infusion and resolves within } 48 \text { hours. } \\
\text { - Usually occurs after the first infusion } \\
\text { - Either does not occur during the following administrations or if it occurs will be mild. } \\
\text { - Managed with oral acetaminophen and hydration }\end{array}$ \\
\hline
\end{tabular}

Zoledronic acid may be of possible benefit in bone metastatic RCC patients.

Almost $50 \%$ of untreated prostate cancer patients with bone metastases will have a minimum one SRE in 2 years of diagnosis. The majority of them will be either pathologic fractures or will require palliative radiotherapy (8). Bone metastasis was detected at autopsy in more than $80 \%$ of the patients who died of prostate cancer (9). The bone metastases in men with prostate cancer are usually osteoblastic although there is an increase in osteolytic activity also due to cancer invasion. As a result of damaged bone homeostasis, bone mineralization is affected and the integrity of the bone is impaired. Subsequently a significant increase in the risk of SREs is observed.

Randomized double-blinded placebo controlled studies in hormone refractory metastatic prostate cancer patients have shown a significantly lower rate of SRE morbidity in the group treated with $4 \mathrm{mg}$ Zoledronic acid every 3 weeks (33\% vs 44\%) and the initial complication was delayed by 5 months. Additionally the total risk of complications decreased by $36 \%$ during the first 24 months $(8,10)$.

The androgen sensitive nature of prostate cancer decreases the necessity of Zoledronic acid. However, the concordance of bone metastasis with androgen deprivation treatment, old age, low body mass index and prolonged treatment increases the risk of SRE. The risk of bone fractures is increased by $7-45 \%$ in patients receiving androgen deprivation treatment $(11,12)$. This increase is associated with the duration of treatment. As an example; the risk of hip fracture is $20 \%$ in the first 3 years of treatment and it increases to $45 \%$ in the 3-5 year period. The risk further increases to $95 \%$ after the duration of treatment exceeds 5 years (13).

According to the National Comprehensive Center Network (NCCN) Guidelines, agents that increase bone health are recommended when the absolute fracture risk warrants therapy. The treatment options include Zoledronic acid, Denosumab and Alendronate. Furthermore the guidelines suggest that either
Zoledronic acid or Denosumab treatment could be initiated in all patients with bone metastasis (14).

\section{Action of Zoledronic acid}

In normal circumstances there is a delicate balance between the osteolytic and osteoblastic metabolism of the bone. Depending on the tissue metastasing the balance may shift towards one side, resulting in disruption of the normal bone metabolism. Osteoblastic activity is more prominent in prostate cancer metastasis while it also has a minor component of osteolytic activity.

Like other,bisphosphonates, zoledronic acid binds to the calcium phosphate bone mineral hydroxyapatite, predominantly localizing at regions of high bone turnover. Additionally, the affinity of zoledronic acid for hydroxyapatite was shown to be higher than that of other bisphosphonates in an in vitro study (15). The activity of zoledronic acid is 100 fold greater than the activity of pamidronate (16). In addition to the mentioned mechanisms zoledronic acid inhibits growth factors and cytokines that cause bone resorption. Some data suggest that zoledronic acid may also inhibit the adhesion of metastatic cells to bone matrix and invasion to the bone tissue (17).

\section{Administration, safety and tolerability of Zoledronic acid:}

The frequency of IV Zoledronic acid related severe side effects are rare and it has a good tolerability and safety margin. The maximum advised dosage is $4 \mathrm{mg}$ and this should not be administered in a time frame of less than 15 minutes. Prior to administration it is advised that all patients are evaluated for kidney function and hydration status. Administration ofroutine daily vitamin $\mathrm{D}$ and calcium is advised.

All bisphosphonates have a potential nephrotoxic effect, especially in patients whose renal function is compromised (18). For this reason it is suggested that patients are not dehydrated prior to treatment and the serum creatinine level is $<3 \mathrm{mg} / \mathrm{dL}$. Even though IV hydration is not mandatory prior to treatment, it would be wise for the patient to have water 2 hours prior to infusion. Electrolyte imbalances may also be observed in Zoledronic acid 
treated patients. In a multicenter study, hypocalcemia requiring treatment was observed in $8 \%$ of patients (19) (Table 1).

Osteonecrosis of the jaw is an interesting complication of longterm zoledronic acid treatment, in which the pathophysiology is to be defined (20). Clinical diagnosis is made by inspection of an area of exposed bone at the jaw, which is present for more than 8 weeks. No prior radiotherapy to the area is an important parameter of diagnosis. Factors that were found to be associated with the disease were; poor oral hygiene, recent dental interventions, chemotherapy, radiotherapy and prolonged bisphosphonate treatment (21). Dental examination prior to initiation of treatment, a good oral hygiene, examination of the oral cavity every 6 months and avoiding oral surgery during the treatment are possible precautions that could be taken in-order to avoid this unwanted event. If invasive dental interventions are necessary, zoledronic acid treatment should be withheld until the dentist indicates that the patient has recovered from the dental procedure (14).

\section{CONCLUSION}

IV Zoledronic acid treatment in bone metastatic prostate and renal cancer is well tolerated. It has potential benefits in delaying the onset of SRE and decreasing the rate of SRE. Zoledronic acid is the best-known and well-defined bisphosphonate in the treatment of bone metastatic prostate cancer. The role of zoledronic acid in the treatment of bone metastatic RCC in the current era of targeted therapies is to be defined.

\section{Conflict of Interest / Çıkar Çatışması}

No conflict of interest was declared by the authors.

Yazarlar herhangi bir çıkar çatışması bildirmemişlerdir.

Peer-review: Internally peer-reviewed.

Hakem değerlendirmesi: iç bağımsız.

\section{Author Contributions / Yazar Katkıları}

Concept / Fikir - M.A.; Design / Tasarım - M.A., Z.T.; Supervision / Denetleme - M.A.; Funding / Kaynaklar - M.A., Z.T., A.Ö.; Materials / Malzemeler - M.A.; Data Collection and/or Processing / Veri toplanması ve/veya işlemesi - Z.T., A.Ö.; Analysis and/or Interpretation / Analiz ve/ veya yorum - M.A, Z.T., A.Ö.; Literature Review / Literatür taraması M.A.; Writer / Yazıyı yazan - M.A.; Critical Review / Eleştirel Inceleme Z.T.; Other / Diğer - Z.T., A.Ö.

\section{REFERENCES}

1. Coleman RE, Major P, Lipton A, Brown JE, Lee KA, Smith M, et al. Predictive value of bone resorption and formation markers in cancer patients with bone metastases receiving the bisphosphonate zoledronic acid. J Clin Oncol 2005; 23: 4925-35. [CrossRef]
2. Coleman RE. Metastatic bone disease: clinical features, pathophysiology and treatment strategies. Cancer Treat Rev 2001; 27: 165-76. [CrossRef]

3. Body JJ. Effectiveness and cost of bisphosphonate therapy in tumor bone disease. Cancer 2003; 97: 859-65. [CrossRef]

4. Flanigan RC, Campbell SC, Clark JI, Picken MM. Metastatik renal cell carcinoma. Curr Treat Options Oncol 2003; 4: 385-90. [CrossRef]

5. Martel CL, Lara PN. Renal cell carcinoma: current status and future directions. Crit Rev Oncol Hematol 2003; 45: 177-90. [CrossRef]

6. Zekri J, Ahmed N, Coleman RE, Hancock BW. The skeletal metastatic complications of renal cell carcinoma. Int J Oncol 2001; 19: 379-82.

7. Palascik TJ, Mouraviev V. Zoledronic acid in the management of metastatic bone disease. Ther Clin Risk Manag 2008; 4: 261-8.

8. Saad F, Gleason DM, Murray R, Tchekmedyian S, Venner P, Lacombe $L$, et al. Long term efficacy of zoledronic acid for the prevention of skeletal complications in patients with metastatic hormone-refractory prostate cancer. J Natl Cancer Inst 2004; 96: 879-82. [CrossRef]

9. Harada M, lida M, Yamaguchi M, Shida K. Analysis of bone metastatic of prostatic adenocarcinoma in 137 autopsy cases. Adv Exp Med Biol 1992;.324: 173-82.

10. Saad F, Gleason DM, Murray R, Tchekmedyian S, Venner P, Lacombe $L$, et al. A randomized, placebo controlled trial of zolderonic acid in patients with hormone-refractory metastatic prostate carcinoma. $J$ Natl Cancer Inst 2002; 94: 1458-68. [CrossRef]

11. Shahinian VB, Kuo YF, Freeman JL, Goodwin JS. Risk of fracture after androgen deprivation for prostate cancer. N Engl J Med 2005; 352: 154-64. [CrossRef]

12. Smith MR, Boyce SP, Moyneur E, Duh MS, Raut MK, Brandman J. Risk of clinical fractures after gonadotropine-releaasing hormone agonist therapy for prostate cancer. J Urol 2006; 175: 136-9. [CrossRef]

13. Ross RW, Small EJ. Osteoporosis in men treated with androgen deprivation therapy for prostate cancer. J Urol 2002; 167: 1952-6. [CrossRef]

14. National Comprehensive Cancer Network Guidelines, Prostate Cancer, Version 2.2013.

15. Nancollas GH, Tang R, Phipps RJ, Henneman Z, Gulde S, Wu W, et al. Noel insights into actions of bisphosphonates on bone: differences in interactions with hydroxyapatite. Bone 2006; 38: 617-27. [CrossRef]

16. Gren JR, Müller K, Jaeggi KA. Preclinical pharmacology of CGP 42'446, a new, potent, heterocyclic bisphosphonate compound. J Bone Miner Res 1994; 9: 745-51. [CrossRef]

17. Boissier S, Ferreras M, Peyruchaud O, Magnetto S, Ebetino FH, Colombel $\mathrm{M}$, et al. Bisphosphonates inhibit breast and prostate carcinoma cell invasion, an early event in the formation of bone metastases. Cancer Res 2000; 60: 2949-54.

18. Klawansky S, Komaroff E, Cavanaugh PF Jr, Mitchell DY, Gordon MJ, Connelly $\mathrm{JE}$, et al. Realtionship between age, renal function and bone mineral density in the US population. Osteoporosis Int 2003; 14: 570-6. [CrossRef]

19. Chennuru S, Koduri J, Baumann MA. Risk factors for symptomatic hypocalcaemia complicating treatment with zoledronic acid. Intern Med J 2008; 38: 635-7. [CrossRef]

20. Guarneri V, Adamus A, Nooka AK, et al. Osteonecrosis of the jaw in patients receiving intravenous bisphosphonate therapy. J Clin Oncol 2006; 24: 8528.

21. Khosla S, Burr D, Cauley J, Dempster DW, Ebeling PR, Felsenberg D, et al. Bisphosphonate-associated osteonecrosis of the jaw: report of a task force of the American society for bone and mineral research. J Bone Miner Res 2007; 22: 1479-91. [CrossRef] 